\title{
Pengaruh Brand Awareness dan Brand Image terhadap Minat Beli Produk Kecantikan Innisfree
}

\author{
Devita Agustin Santoso, Rezi. Erdiansyah, Muhammad Adi Pribadi \\ devita.santoso@hotmail.com,rezie@fikom.untar.ac.id,adip@fikom.untar.ac.id \\ Fakultas Ilmu Komunikasi Universitas Tarumanagara
}

\begin{abstract}
Korean beauty trend began to enter the global market, including Indonesia. One of which was Innisfree, a korean beauty brand that sell skin care and beauty products made with natural ingredients from Jeju Island. Innisfree launch it's first official store for Indonesian market in 2017 at Central Park Mall, Jakarta. This research will discuss the influence of brand awareness and brand image towards Innisfree beauty products purchase intention. The respondents of this research were the users of Innisfree beauty product, with 100 participants. Research was conducted using a quantitative method with quota sampling techniques in Innisfree beauty products user. The analytical method used in this research is Validity Test, Reliability Test, Determination Coefficient Test, Correlation Coefficient Test Multiple Linear Regression Test, F Test, and T Test. The results of this study indicate that brand awareness and brand image have a significant influence on Innisfree beauty products purchase intention.
\end{abstract}

Keywords: Brand Awareness, Brand Image, Purchase Intention, Beauty Products

\begin{abstract}
Abstrak
Tren kecantikan korea mulai memasuki pasar global, termasuk Indonesia. Salah satunya adalah Innisfree, brand produk kecantikan korea yang menjual perawatan kulit dan kecantikan dengan menggunakan bahan-bahan alami dari Pulau Jeju. Innisfree meluncurkan gerai resmi di pasar Indonesia pada tahun 2017 di Central Park Mall. Penelitian ini membahas mengenai pengaruh brand awareness dan brand image terhadap minat beli produk kecantikan Innisfree. Responden penelitian adalah pengguna produk kecantikan Innisfree, dengan jumlah 100 responden. Penelitian dilakukan menggunakan metode kuantitatif dengan teknik pengumpulan data quota sampling. Teknik analisis yang digunakan dalam penelitian ini adalah Uji Validitas, Uji Reliabilitas, Uji Koefisien Determinasi, Uji Koefisien Korelasi, Uji Regresi Linier Berganda, Uji F, dan Uji T. Hasil penelitian ini menyatakan bahwa secara bersama-sama brand awareness dan brand image memiliki pengaruh yang signifikan terhadap minat beli produk kecantikan Innisfree.
\end{abstract}

Kata Kunci: Brand Awareness, Brand Image, Minat Beli, Produk Kecantikan

\section{Pendahuluan}

Berkembangnya era globalisasi, mendorong penyebaran informasi dan tren kecantikan dari berbagai tempat di dunia. Kemunculan beragam tren kecantikan internasional membuat daya beli produk kecantikan semakin meningkat dan memciptakan persaingan antar perusahaan untuk mengembangkan bisnisnya memasuki pasar global. Salah satunya adalah tren kecantikan Korea yang mulai memasuki pasar Indonesia. Adanya fenomena Korean Wave yang melanda Indonesia menjadi salah satu faktor pendorong munculnya tren tersebut. Hal ini dikarenakan banyaknya tayangan entertainer Korea mulai dari drama, film, dan juga musik yang 
menampilkan kecantikan natural wanita korea. Hal ini dimanfaatkan oleh brandbrand kecantikan Korea yang mulai memasuki pasar Indonesia salah satunya brand Innisfree. Innisfree adalah brand kecantikan ternama dari Korea yang menawarkan berbagai macam produk kecantikan dengan menggunakan bahan-bahan alami dari Pulau Jeju. Namun sebelumnya sudah banyak brand kecantikan korea dengan produk sejenis telah beredar lebih dulu di Indonesia seperti, The Face Shop, Etude House Skin Food, Natural Republic, dan sebagainya. Disaat inilah konsumen memiliki sebuah sikap terhadap suatu merek (brand), dimana konsumen akan mengenali, mempelajari, dan mengevaluasi sebuah merek yang disukai maupun tidak disukai. Dengan ini penulis ingin mengetahui apakah brand awareness dan brand image mempengaruhi minat beli produk kecantikan Innisfree.

Landasan Teori, Brand Awareness: Menurut David A. Aaker (1997), kesadaran merek adalah kemampuan seorang calon pembeli untuk mengenali ataupun mengingat kembali bahwa suatu merek merupakan bagian dari kategori produk tertentu. Penulis menggunakan 6 elemen dimensi menurut Kotler \& keller (2009) meliputi, memorable (elemen merek dapat diingat dan dikenali oleh konsumen), likeability (elemen merek disukai secara visual, verbal, dan cara lain), meaningful (elemen merek dapat dipercaya dan dapat digunakan untuk mengidentifikasi kategori yang berhubungan dengannya), transferable (elemen merek dapat digunakan untuk mengenali produk baru), adaptable (elemen merek mudah disesuaikan dan dapat diperbaharui), dan protectable (elemen merek dapat dilindungi secara hukum dan kompetitif) sebagai indikator untuk mengetahui seberapa jauh kesadaran konsumen terhadap suatu merek.

Brand Image: Menurut Kotler dan Keller (2007) brand image adalah kombinasi dari keseluruhan (nama, istilah, simbol, rancangan dan lain-lain) yang ditujukan untuk mengenali barang atau jasa penjual sehingga berbeda dengan barang atau jasa yang dimiliki oleh pesaing. Penulis menggunakan 3 unsur yang ada pada brand image menurut Keller (1993) yaitu, attribute (aspek internal dan eksternal dari produk), benefits (secara fungsi, emosional, sosial, dan simbol), dan brand attitude (penilaian evaluative terhadap kepercayaan terhadap produk sebagai indikator untuk mengetahui efektivitas citra merek.

Minat Beli: Menurut Kotler dan Keller (2005) minat beli konsumen adalah sesuatu yang timbul ketika melihat sebuah produk yang kemudian timbul ketertarikan untuk mencoba produk tersebut sehingga pada akhirnya muncul keinginan untuk membeli produk tersebut. Penulis menggunakan 4 faktor yang mengidentifikasi minat beli menurut Ferdinand (2002) yaitu minat transaksional (sudah memiliki minat untuk membeli produk), minat preferensial (akan berpindah produk jika terjadi sesuatu terhadap produk), minat referensial (membeli serta merekomendasikan produk ke orang lain), dan minat eksploratif (mencari informasi terkait mengenai produk yang diminati atau dicarinya) sebagai indikator untuk mengetahui apa saja rangsangan-rangsangan yang membuat konsumen timbul keinginan untuk membeli suatu produk.

\section{Metode Penelitian}

Penelitian dilaksanakan dengan menggunakan metode kuantitatif. Penyebaran kuesioner dilakukan dengan teknik quota sampling kepada 100 responden pengguna produk kecantikan Innisfree. Terdapat 3 Variabel yang diukur dalam penelitian ini yakni, 
a. Brand awareness sebagai variabel bebas atau independen (X1) menggunakan 6 dimensi elemen dalam membangun kesadaran merek menurut Kotler dan Keller (2009) meliputi, memorable, meaningful, likeability, transferable, adaptable, dan protectable.

b. Brand image sebagai variabel bebas atau independen (X2) menggunakan 3 dimensi menurut Keller (1993) yaitu, attribute, benefits (manfaat), dan brand attitude.

c. Minat beli sebagai variabel terikat atau dependen (Y) menggunakan 4 dimensi menurut Ferdinand (2002) yaitu minat transaksional, minat preferensial, minat referensial, dan minat eksploratif.

\section{Hasil Temuan dan Diskusi}

Penelitian diawali dengan uji validitas, uji reliabilitas terhadap 13 pernyataan variabel brand awareness, 13 pernyataan variabel brand image dan 4 pernyataan variabel minat beli yang telah diisi oleh 106 responden melalui penyebaran kuisioner dengan menggunakan media Google Form. Sebanyak 100 orang berhasil mengikuti kuisioner ke tahap ke dua dan 6 orang lainnya tidak dapat melanjutkan kuisioner selanjutnya karena tidak mengetahui atau tidak pernah menggunakan produk kecantikan Innisfree. Kemudian selanjutnya, pada butir pertanyaan dilakukan uji validitas dan uji reliabilitas. Hasil analisis data responden menunjukkan bahwa butir pernyataan ketiga variabel penelitian valid dan reliabel yang menunjukkan bahwa data/pernyataan layak digunakan sebagai alat ukur penelitian. Berdasarkan hasil tersebut maka hasil sebaran data telah memenuhi syarat pengujian lainnya yang meliputi uji koefisien korelasi, uji regresi linier sederhana, uji koefisien determinasi, uji t, dan uji $f$.

Hasil Uji Koefisien Korelasi dengan teknik Product Moment Pearson Correlations

\begin{tabular}{|c|c|c|c|c|}
\hline & & $\begin{array}{c}\text { Brand } \\
\text { Awareness }\end{array}$ & Brand Image & Minat Beli \\
\hline \multirow[t]{3}{*}{ Brand Awareness } & Pearson Correlation & 1 & $.768^{* *}$ & $.565^{* *}$ \\
\hline & Sig. (2-tailed) & & .000 & .000 \\
\hline & $\mathrm{N}$ & 100 & 100 & 100 \\
\hline \multirow[t]{3}{*}{ Brand Image } & Pearson Correlation & $.768^{* *}$ & 1 & $.652^{* *}$ \\
\hline & Sig. (2-tailed) & .000 & & .000 \\
\hline & $\mathrm{N}$ & 100 & 100 & 100 \\
\hline \multirow[t]{3}{*}{ Minat Beli } & Pearson Correlation & $.565^{* *}$ & $.652^{* *}$ & 1 \\
\hline & Sig. (2-tailed) & .000 & .000 & \\
\hline & $\mathrm{N}$ & 100 & 100 & 100 \\
\hline
\end{tabular}

Hasil uji koefisien korelasi menunjukkan bahwa terdapat pengaruh yang signifikan antara brand awareness dan brand image terhadap minat beli produk kecantikan Innisfree dengan angka korelasi 0,660. Ini berarti jika brand awareness dan brand image meningkat maka minat beli produk kecantikan Innisfree juga akan 
meningkat, dan sebaliknya jika brand awareness dan brand image menurun maka minat beli kecantikan produk Innisfree juga akan menurun.

Hasil Uji Koefisien Determinasi $\left(\mathbf{R}^{2}\right)$

Model Summary ${ }^{\mathrm{b}}$

\begin{tabular}{ll|r|r|r}
\hline Model & R & R Square & \multicolumn{1}{c}{$\begin{array}{c}\text { Adjusted R } \\
\text { Square }\end{array}$} & $\begin{array}{l}\text { Std. Error of } \\
\text { the Estimate }\end{array}$ \\
\hline 1 & $.660^{\mathrm{a}}$ & .436 & .424 & 1.25857 \\
\hline
\end{tabular}

Hasil uji koefisien determinasi menyatakan bahwa Brand awareness dan brand image diprediksi cukup mempengaruhi minat beli produk kecantikan Innisfree sebesar 43,6\%, sedangkan 56,4\% lainnya dipengaruhi oleh variabel-variabel yang tidak diteliti.

Tabel Hasil Uji Regresi Linier Berganda dan Uji T Coefficients $^{\mathbf{a}}$

\begin{tabular}{llr|r|r|r|r}
\hline Model & & \multicolumn{2}{c|}{$\begin{array}{l}\text { Unstandardized } \\
\text { Coefficients }\end{array}$} & $\begin{array}{l}\text { Standardized } \\
\text { Coefficients }\end{array}$ & t & \multicolumn{2}{l}{ Sig. } \\
& \multicolumn{1}{c|}{ B } & Std. Error & Beta & & \\
\hline 1 & (Constant) & 1.100 & 1.403 & & .784 & .435 \\
& Brand Awareness & .069 & .053 & .156 & 1.308 & .194 \\
Brand Image & .204 & .046 & .533 & 4.470 & .000 \\
\hline
\end{tabular}

Hasil uji regresi linier berganda dan uji t menyatakan bahwa nilai koefisiensi regresi brand awarenesss adalah sebesar 0,069 dengan signifikansi 0,194 yang artinya $\operatorname{sig}(\mathrm{p})<0,05$, maka dinyatakan tidak terdapat pengaruh yang signifikan antara brand awareness terhadap minat beli produk kecantikan Innisfree. Sedangkan nilai koefisiensi regresi brand image adalah sebesar 0,204 dengan signifikansi 0,000 yang artinya $\operatorname{sig}(\mathrm{p})<0,05$, maka dinyatakan terdapat pengaruh yang signifikan pada variabel brand image terhadap minat beli produk kecantikan Innisfree.

Tabel Hasil Uji F ANOVA $^{\mathrm{a}}$

\begin{tabular}{llr|r|r|r|r}
\hline Model & & Sum of Squares & df & Mean Square & F & Sig. \\
\hline 1 & Regression & 118.593 & 2 & 59.297 & 37.435 & $.000^{\text {b }}$ \\
& Residual & 153.647 & 97 & 1.584 & & \\
& Total & 272.240 & 99 & & & \\
\hline
\end{tabular}

Hasil uji $\mathrm{F}$ menyatakan bahwa nilai $\mathrm{F}$ adalah 37,435 dengan signifikansi 0,000 yang berarti bahwa secara bersama-sama brand awareness dan brand image memiliki pengaruh yang signifikan terhadap minat beli produk kecantikan Innisfree.

\section{Simpulan}

Berdasarkan hasil dari penelitian kuantitatif mengenai pengaruh brand awareness dan brand image terhadap minat beli produk kecantikan Innisfree kepada populasi pengguna produk kecantikan Innisfree dapat dikatakan bahwa brand 
Devita Agustin Santoso, Rezi. Erdiansyah, Muhammad Adi Pribadi: Pengaruh Brand Awareness dan Brand Image terhadap Minat Beli Produk Kecantikan Innisfree

awareness dan brand image memiliki pengaruh yang signifikan terhadap minat beli produk kecantikan Innisfree sebesar 43,6\%

\section{Ucapan Terima Kasih}

Pada kesempatan ini penulis mengucap syukur dan terima kasih kepada Tuhan Yang Masa Esa, serta kepada pembimbing dan co pembimbing yang telah membantu penulis dalam menyelesaikan skripsi dan jurnal ini yaitu Bapak Dr. Rezi. Erdiansyah, M.Si, dan Bapak Dr. Muhammad Adi Pribadi., S.E., M. IB., M.Com, dan kepada keluarga, sahabat, responden penelitian, dosen Fakultas Ilmu Komunikasi Universitas Tarumanagara dan pihak-pihak lainnya yang telah berkontribusi dalam proses penyelesaian penelitian ini.

\section{Daftar Pustaka}

Aaker, David A. (1997). Manajemen Ekuitas Merek: Memanfaatkan Nilai dari Suatu Merek. Alih Bahasa: Aris Ananda. Jakarta: Mitra Utama

Ferdinand, Augusty. (2002). Pengembangan Minat Beli Merek Eksitensi. Semarang: Badan Penerbit Universitas Diponogoro

Keller, Kevin L. (1993). Conceptualizing, Measuring, and Managing Customer Based-Based Brand Equity. Journal of Marketing, Vol. 57 No. 1, pp 1-22

Kotler, Philip dan Kevin Lane Keller. (2005). Manajemen Pemasaran Jilid 1 dan 2. Jakarta: PT Indeks Kelompok Gramedia

Kotler dan Kevin Lane Keller. (2007). Manajemen Pemasaran Millenium Edition. Ahli Bahasa: Benyamin Molan, edisi 12. Jakarta: PT Indeks

Kotler, Philip dan Kevin Lane Keller. (2009). Manajemen Pemasaran (Edisi 13). Jakarta: Penerbit Erlangga

Kriyantono, Rachmat. (2006). Teknik Praktis Riset Komunikasi. Jakarta: Kencana Prenadamedia Group 